Implementing Diversity Management in Retailing: exploring the role of organisational context

\author{
Dr Carley Foster \\ Department of Strategic Management \& Marketing \\ Nottingham Business School \\ Nottingham Trent University \\ Burton Street \\ Nottingham \\ NG1 4BU \\ Tel: 01158484691 \\ Fax: 01158484707 \\ e-mail: carley.foster@ntu.ac.uk
}




\title{
Implementing Diversity Management in Retailing: exploring the role of organisational context
}

\begin{abstract}
:
Diversity management is a means of managing customer and employee differences for the benefit of the organisation. This qualitative study considers how contextual factors influence diversity management implementation in different retailing environments. Exploratory research was conducted in three SBUs of a UK retailing group: the UK high street SBU, the US operations and the online SBU. Despite different cultural, legal and historical differences between the UK and US, these factors did not lead to significantly different ways of dealing with diversity in the UK high street and US businesses. Instead the extent to which individual differences were recognised was influenced by the selling environment and the retailer's size and structure. The paper recommends that retailer's need to develop a 'home-grown' approach to diversity management that acknowledges their organisational context.
\end{abstract}

Keywords: Retail, HR, diversity management

\section{Introduction}

Diversity management represents a recent development in the equality literature and the workplace (Thomas 1990). A key theme of this approach is the recognition of individual customer and employee differences, such as age, race and disability, in organisational practices so as to achieve business benefits (Kandola and Fullerton 1998; Kirton and Greene 2000). While it can be argued that the business rationale for diversity management is appealing to retailers, there is a lack of research exploring managing diversity in retailing practice. 
Compared to the private sector, the UK public sector has generally been '...demonstrably active in terms of the equality agenda' (Maxwell et al. 2003, p. 245). As a means of improving the quality of services delivered, for many public services emphasis is placed on employing front line workers that share the same diversity as the community they serve. A consequence of this is that the limited amount of UK diversity management research that exists has typically explored the approach in public organisations rather than commercial industries, like retailing, which also serve diverse communities (Gill 1996; Wilson and Iles 1999). In particular investigating the reality of implementing diversity management in the retail sector has not been adequately considered, despite the rising number of retailers adopting formal diversity statements. The John Lewis Partnership (John Lewis Partnership 2004), for example, states that 'Embracing diversity helps us to attract, retain and develop Partners, whilst developing a creative and innovative culture and appealing to a wide customer base'. Similarly Tesco (Tesco 2004) has an 'Inclusivity' statement which explains that 'Diversity benefits a business in many ways, including greater customer and staff loyalty'. Yet it is unclear as to how such statements are operationalised, particularly in terms of how contextual factors affect implementation. This research therefore addresses weaknesses in existing knowledge by exploring how diversity management is implemented in retailing, that is the degree to which employee and customer differences, like age, gender and ethnicity, are recognised in a retailer's activities so as to attain business benefits.

The paper begins with a review of the diversity management literature, paying particular attention to why this approach might be appealing to retailers and the gaps in present knowledge. Next an explanation of the research design is provided, 
followed by an exploration of the key findings that have emerged from the research. The paper concludes by considering the implications the findings have for both retailers and the diversity management literature.

\section{Background}

It is suggested that a number of factors have prompted organisational interest in the managing diversity approach. Shifts in demographics and skills shortages have forced organisations to extend their recruitment activities to include people they would not normally target (Hogarth and Barth 1991). This, combined with the fact that many organisations now employ staff from different countries as a result of expansion, mergers and take-overs, means that workforces are becoming more diverse (Cartwright and Cooper 2000). Alterations to customer demographics have also prompted interest in diversity management. Increasingly organisations are moving into previously unexploited 'minority' markets that are significant in size, requiring them to understand the different needs of their diverse customer base in order to develop appropriate products and services.

Prahalad (2004), for example, has urged organisations to move away from targeting products and services at the developed world and instead create offerings aimed at the poor. According to Prahalad this market represents a huge opportunity as the poor equate to two-thirds of the world's population. Similarly Michael Porter (Initiative for a Competitive Inner City 1998) has encouraged US retailers to pursue opportunities in inner cities. He states that 'Inner cities represent the largest and closest emerging market in the world'. This market equates to $7 \%$ of all US retail spending. In terms of appealing to specific customer characteristics like ethnicity and race, in 1998 
Sainsbury in its largest store in London opened a separate kosher deli counter, the first of its kind in the UK. All staff working on this counter received specialist training on Jewish dietary procedures (The Grocer 1998). More recently in 2003 HSBC Bank plc became the first UK bank to offer Islamic financial products (Hebburn 2003).

In addition to demographic changes, interest in diversity management has also arisen from the mixed success of anti- discrimination legislation (Cassell 2001). While success has been attained in some areas, such as reducing levels of overt discrimination in recruitment advertising (Wright and Storey 1997), overall equal opportunity initiatives have been largely ineffective at achieving their objectives (Sheffield et al. 1999). Thus an approach like managing diversity, which unlike the equal opportunities approach is promoted on the basis of the business case rather than the legal or moral arguments, may actually prompt organisations to have a greater concern for workplace equality (Barmes and Ashtiany 2003).

Proponents of managing diversity contend that all types of individual differences should be recognised and valued in organisational practices (Schneider 2001). This 'inclusive' definition of diversity is in contrast to the narrow set of differences, namely race, gender and disability, referred to in UK anti- discrimination legislation. While there is agreement in the literature to the principle that diversity management should adopt a broad definition of 'difference', researchers have classified these differences in a number of ways. Wilson and Iles (1999), for example, have categorised them as 'primary' (e.g. age and gender) and 'secondary' (e.g. class and personality). Conversely, Kandola and Fullerton (1994) refer to visible (e.g. race and 
gender) and non-visible differences (e.g. some aspects of disability). Nevertheless, advocates of the approach argue that these customer and employee differences, however defined, should be viewed as an asset (Wilson and Iles 1999). This implies then, that individuals should be treated differently according to their characteristics so as to achieve business advantages. So, for example, it is suggested that recognising the different employment needs of staff, such as fulfilling requests for religious based leave or parental leave, will lead to more loyal and committed employees (Lewis et al. 2000), increased levels of job satisfaction resulting in a reduction in absenteeism and labour turnover (Cox 1993) and an improvement in the quality of relations amongst staff (McEnrue 1993). Furthermore by valuing and harnessing the individual differences of staff, such as their age or race, organisational creativity and innovation is reported to improve through the formation of new ideas (Copeland 1988), as is the image of the organisation through a broadening of its appeal to different types of customers and potential job applicants (Thomas and Ely 1996; Whitehead 1999). Littlewoods, for example, reportedly increased their Leicester store profits by $24 \%$ when Asian store staff suggested that they should sell products celebrating Diwali in addition to Christmas related offerings (Pickard 1999). For the purposes of this study then, diversity management is interpreted as an organisational approach that recognises, values and harnesses a broad range of individual differences in customers and employees and by treating people differently according to their needs business advantages can be realised.

The business benefits of diversity management identified in the literature would be particularly advantageous for retailers. Typically, retailers experience high rates of staff turnover (Broadbridge 2000). An approach like managing diversity, which it is 
claimed can improve retention rates through valuing individual differences, would therefore be attractive (Kandola and Fullerton 1998). Furthermore, given the visible nature of the industry, recognising customer differences in marketing activities could have a positive impact on the retailer's image as a place to shop and work. Sales staff in particular, play a key role in creating a favourable store image (McGoldrick 2000). Indeed Uncles (1995) has argued that whilst elements like products and price can be imitated by competitors, differentiation can be achieved through distinctive service delivered by sales staff. In particular there is evidence to suggest that customers prefer to interact with sales staff that share their visible diversity like age and ethnicity (Johnson-Hillery et al. 1997; Shanmuganthan 2003).

Employing front line staff from non-traditional recruitment sources may also help retailers tackle skills shortages, an additional problem experienced in the industry (Retail Week 2001), since it will encourage employers to look for staff in alternative labour markets. During the 1990s the DIY retailer B\&Q introduced a policy of actively recruiting store staff aged over 50 in order to overcome labour shortages. Older staff, rather than younger staff, were also more likely to offer expert assistance to customers as a result of their DIY experiences gained through being a homeowner (Hogarth and Barth 1991). This trend for employing staff over 50 has also been visible in supermarkets. In 1999 Asda opened its first store where over half of all employees were aged over 50. Other stores followed suit and as a result absenteeism in these stores was reportedly a third lower than in the rest of Asda's UK outlets (Asda 2002). 
Despite the apparent appeal of diversity management, it is unclear as to how organisations should implement the approach, particularly in relation to recognising individual differences in practice. Indeed much of the literature implies that the application of diversity management is straightforward, neglecting the role contextual factors might have in its implementation. So, for example, the managing diversity literature is heavily based upon the US experience of 'difference' and has failed to acknowledge the historical, demographic and cultural contexts of other countries (Agocs and Burr 1996). To take one example, a comparison of UK and US demographics shows considerable differences. In 2000 approximately $29 \%$ of the US population were non-white, by 2050 it is predicted that this figure will rise to $49 \%$ (Newsweek 2000). In contrast, in $2001 / 2$ only $8 \%$ of the UK population were from ethnic minority groups (National Statistics 2002). Thus, as Agocs and Burr (1996, p. 42) have argued 'popularity of diversity management in the USA is not a good reason to adopt this approach if it is a poor fit'.

There are also problems with the rationale for adopting a managing diversity approach. It is claimed that there is a lack of empirical evidence to show that diversity management will actually bring business benefits to an organisation (Mavin and Girling 2000). For example, employing a diverse workforce could be difficult to manage due to conflicts of interest which may hamper decision-making rather than improve it through the generation of different ideas (Caudron 1994). There is also a danger that organisations targeting 'minority' markets may alienate their 'majority' customer base (Engel 1995). It is also unclear as to how an organisation should recognise and harness individual differences whilst complying with antidiscrimination legislation based on a 'sameness of treatment' approach. Indeed this is 
an important practical issue that has been overlooked in the diversity management literature. A key principle underpinning the equal opportunities framework is the notion of neutrality (Fredman 2001). Put another way, workplace fairness equates to consistency of treatment (Hepple 2001). Demonstrating compliance to this principle underpinning the anti-discrimination legislation has therefore led organisations to implement policies that are procedurally fair; that is they aim to treat people the same (Harris 2000). So, for example, when interviewing, typically all candidates are asked to respond to the same set of questions.

In addition the literature fails to provide guidance on how an organisation should manage staff on an individual basis when the workforce is large in number and located in several different areas, as the retail workforce frequently is. Unsurprisingly the implementation difficulties associated with diversity management have led Bond and Pyle (1998, p. 252) to comment that '...overall commitment [to managing diversity] is at best unstable and ambivalent'.

Retailing offers a suitable industry environment for exploring diversity management because not only does it experience staffing problems such as high turnover and skills shortages that advocates claim the approach can help resolve, but front-line workers are also visible to customers. Employing staff with different characteristics may help retailers to attract more people to the organisation and help them to secure sales in a highly competitive environment, particularly if these characteristics reflect the community the retailer serves. Furthermore, since the retail sector employs large numbers of people typically in dispersed locations it provides an appropriate setting for considering how people's differences might be managed. The main purpose of 
this study, therefore, was to explore how diversity management is implemented in retailing, paying particular attention to the role contextual factors play in its application. Deriving from this objective were two further aims. These were: to investigate interpretations of workplace fairness that is, issues related to differential treatment and neutrality of treatment and to consider how realistic the business case for recognising customer and employee differences is in practice for retailers.

\section{Research Design}

Since the main aim of the study was to investigate how diversity management is implemented in retailing including an exploration of how contextual factors might influence implementation, the research assumed a qualitative approach. This is because a qualitative approach emphasises the importance of respondents' interpretations whist considering contextual factors (Bryman 1989). According to Yin (1994), research that explores 'how' questions, as this study does, are best served by a case study research design. The study therefore adopted a multiple case study research design as it is argued this design provides more persuasive results than a study that centres upon one single case (Herriott and Firestone 1983). Each 'case' was a separate strategic business unit (SBU) belonging to a large, well-known UK based retailing group. Three SBUs formed the focus of this study, these were the UK high street SBU, the US SBU and the online SBU (based in the UK).

Although these three SBUs functioned separately from one another in terms of, for example, their day-to-day operations and management structure, they nevertheless shared a number of constants. For example, they all operated in the same area of retailing (entertainment, education and information) and all worked towards meeting 
the same corporate objectives set by management at the retail group, such as strengthening the corporate brand name either through new routes to market or via own brand products. However, in other ways like how the SBU had evolved, the structure of the SBU, the location of the SBU and the nature of customer contact, the SBUs differed. It was felt that these different contextual factors could potentially affect the way in which diversity management was implemented in the SBUs and for this reason, they were deemed as appropriate 'cases'. An overview of some of the key structural differences between the three SBUs is provided in Table 1.

\section{INSERT TABLE 1 HERE}

Materials were collected over a period of twelve months using a combination of semistructured interviews, observations and documentary evidence; the key research methods associated with qualitative research (Bryman 1989). These complementary methods were chosen because, in brief, semi-structured interviews enable the researcher to be exploratory in their investigations, documents allow the researcher to gain an understanding of the values and beliefs of those being studied and observations assist in gaining a better understanding of the subtleties of meaning (Marshal and Rossman 1995). A total of 40 interviews were conducted. Approximately half of the interviewees were female, $75 \%$ were white, $8 \%$ had a visible disability and two thirds were aged between 30 and 49 years. Respondents were selected on the basis of their involvement in equality and diversity initiatives at both the policy generation and implementation levels. Given the size of the US and UK high street organisations and the fluid nature of job responsibilities in the online operation, the researcher employed snowball sampling to select appropriate people to interview; a technique that relies on participants to identify other suitable candidates to interview (Frankwick et al. 1994). Consequently respondents included sales 
assistants, store managers, regional $\mathrm{HR}$ and general managers, senior $\mathrm{HR}$ and marketing specialists, buyers and customer service managers.

The interviews explored themes relating to: the role of their SBU and other SBUs in the retail group, the respondent's job role and career progression, equality and diversity initiatives in their SBU and equality and diversity policies more generally. In addition to these themes, the respondents were asked to comment on four short fictional scenarios (two HR related and two marketing related) in the interview. The scenarios attempted to encapsulate the essence of a managing diversity approach and an equal opportunities approach as described in the literature. By using an employee benefits system as an example, one HR scenario described how a retailer might treat staff the same by ignoring individual needs and issuing every employee with the same benefits package (equal opportunities). The other HR scenario described how employees could choose any benefit they wanted according to their individual requirements (diversity management). The two marketing scenarios attempted to explore how a diverse and non-diverse workforce might influence the marketing strategies of a retailer. Although the differences between diversity management and equal opportunities were simplified for the purposes of the scenarios, the main aim of the scenarios was to provide a useful way to show how diversity management and equal opportunities might operate in practice, particularly as research suggests that uptake of the managing diversity approach in organisations is limited (Mavin and Girling 2000). The role of the scenarios, therefore, was to act as a prompt to discussions. Respondents were asked to read these scenarios and then to discuss the disadvantages and advantages of each and to provide any other comments they might have on the different approaches described in the scenarios. 
A variety of observations were also made, this included recording observations relating to in-store merchandising, recruitment and training events and the office/instore working environment. Documents, such as annual reports, internal best practice documents, job adverts and employee handbooks were also analysed.

Analysis of the materials used a combination of the computer programme NUD*IST and manual 'pen and paper' methods. NUD*IST assisted the organisation and retrieval of materials according to a set of codes developed by the researcher. The latter, more creative stages of the analysis, such as exploring the relationships between coded materials, were conducted manually. Codes were initially derived from the literature review and research questions. These were then developed and revised according to themes that emerged from the transcribed interviews, recorded observations and document contents.

\section{Findings}

The findings show that implementing managing diversity is not straightforward, particularly in relation to recognising customer and staff differences. Analysis of the materials indicates that the size and structure of the SBU and the selling environment impacted upon the SBU's ability to manage diversity in practice. Specifically the size and structure of the organisation influenced the three SBU's ability to recognise employee differences and the nature of the selling environment affected the three SBU's ability to recognise customer differences.

\section{The selling environment}


For the online SBU, contact with the general public was through electronic means. All products could be purchased through their website and interactive television. Customer orders were either fulfilled from a small amount of stock housed on the premises, typically consisting of fast moving lines, or through direct orders made with suppliers which were then dispatched to customers via the online SBU. Since this method of fulfilling orders meant that the financial risk associated with warehousing stock was minimised and the number of products available to view by customers on the website was relatively unrestricted, the SBU was able to offer 2.1 million products, reflecting a vast range of different customer interests. The fiction book category, for instance, consisted of 100,000 lines and the health section had approximately 14,500 books. More specifically the 'Coping with disability' category had around 200 books. In terms of sales, describing the online organisation's broad product range, a senior manager remarked:

'There are no big product sections [on the website]... I think the biggest category we've got comes up as $5 \%$ of sales'

Respondents from all three SBUs believed that adapting product lines to suit the diverse needs of the community served was 'fairer' than treating all customers the same in terms of product and service offerings, as evident in their responses to the marketing related scenarios. One interviewee commented for example that:

'In that marketing scenario you are giving your customers what they need. If you're not a native English speaker, it's probably easier for you to listen in your own language or read in your own language.' 
However, despite these comments the reality was much different in the US and UK high street SBUS. In contrast to the online SBU, the US and UK high street SBUs were limited in terms of the variety of products they could offer to their customers. On the whole, each store sold products in the same broad category, for example, books, newspapers and magazines, to ensure continuity across the outlets, as a UK high street store manager commented:

'The [UK high street] company wants all our customers to be able to go into any of our stores and find the same things, in the same place and on the same displays'

Depending on the size of the store, the range of products within each category was adapted according to the available shelf space. Nevertheless, product ranges were 'mainstream' in that they appealed to the mass market, such as national newspapers and best selling fiction books. Occasionally merchandise was adapted to the needs of the local market. For example the US outlets located in hotels, adapted their range according to whether the store was positioned in a resort (e.g. sun creams) or conference hotel (e.g. business newspapers). One US buyer describing their decision to limit the extent to which their merchandise was adapted to the different needs of customers stated that:

'As much as the organisation would like to be everything to everybody we can't...we have to go back to the 80/20 rule. We have to see what drives our business and then how we can layer the ambience and flavour of the local atmosphere on to the store and still have that balance of profit.' 
Similarly in the UK, stores located in areas with diverse communities sold a small number of products that reflected the needs of different ethnic groups, as explained by one UK store manager:

'Because there's a large Asian population in Leicester, we have a lot of people asking for the Highway Code in Urdu so we order that in. In Northampton we had a high Irish population and we did really well on sales of St Patrick's Day cards. So 'yes' we try and cater for some tastes.'

The reason for the limited adaptation of product ranges was provided by a UK marketing manager. Contrasting with the diversity management literature which proposes that there are benefits to be gained from recognising different customer needs in products and services, this respondent suggests that adopting this approach would not be beneficial for his SBU:

'...our customer base is so, so massive. We don't target those small sectors...it probably comes down to resources. If you divide your market into little groups of 1 or $2 \%$, you end up with 50 or 60 groups which becomes very difficult for the business to understand, to manage and to deal with.'

The approach adopted by the UK high street and US SBUs therefore differed from the online SBU. The nature of the online operations meant that a variety of different customer needs could be recognised in their merchandise. However, the products offered by the two more 'traditional retailing' SBUs were restricted to the amount of shelf space available in store. In terms of square footage, on average, the US stores 
were one fifth of the size of the UK high street stores and the largest of all the outlets in both SBUs (the larger UK high street flagship stores) stocked around 45,000 lines. Although around the same number of stocked items as a large supermarket (Dreze et al. 1994), in comparison to the online SBU different customer needs in these two SBUs were recognised in only a limited manner. Furthermore, by offering more or less the same product categories in every outlet, marketing activities remained manageable. This was important given the size and structure of the US and UK high street SBUs.

\section{Size and structure}

For the purposes of reporting the findings, the size and structure of the SBUs have been grouped together as an important factor influencing diversity management implementation. In this study the analysis indicated that these factors were closely interrelated, particularly the relationship between the reporting structure, the location of staff and the amount of staff employed. So for example, in the UK high street and US SBUs store, regional and head office levels were necessary to facilitate the management of the high numbers of employees situated in widely dispersed locations.

At the time of the study the UK high street SBU employed 17,000 staff and had around 550 stores nationwide. Based on observations, limited employment data and interview responses, all levels of this business appeared to have disability, age and gender diversity. Unfortunately no employment data relating to the exact profile of the workforce was available. Generally stores tended to have more ethnic diversity than the head office and regional levels, especially those located in areas with a high proportion of people from ethnic minorities. So, for example, $90 \%$ of weekend staff at 
the store in which the researcher spent three weeks collecting materials were Asian. This store was positioned in a city with a large number of Asian residents. The US SBU had approximately 3,600 employees and 570 stores located in major airports and hotels in the US, Canada and South America. This retailer had much more ethnic diversity than the UK high street SBU. Meeting employee diversity targets set by the government combined with the fact that the US is more racially diverse than the UK meant that, according to respondents, $70 \%$ of all US staff were female and over half were from ethnic 'minority' groups. Estimates of the proportion of staff with other aspects of diversity like age and disability were not provided by this SBU.

Like many large retailers, both these SBUs disseminated policies 'top-down' through their well ordered structure, that is from head office to store level via regional and district levels. Such policies had evolved gradually, in keeping with the steady growth of both SBUs so that procedures existed for all matters relating to day-to-day operations. Consequently, there was a considerable amount of bureaucracy within these companies. HR policies were generated and maintained by head office HR staff and then communicated through seminars, workshops and written procedures in the form of best practice manuals. These manuals were continually referred to by store staff as they provided detailed guidance on matters like recruitment, equal opportunities and diversity. Emphasising the importance of the manuals as a source of equal opportunities related information, the following UK store manager stated that:

'The manuals have got everything to the letter and are correct. If you read them you can't go wrong.' 
The role of the HR function had an influence on the extent to which the US and UK high street retailers were able to adopt a managing diversity approach, particularly in relation to recognising employee differences. There was strong evidence to suggest that the HR function in both the US and UK high street SBUs had a 'policing' role (Harris 1999), as demonstrated by the following remark from a senior UK HR manager:

'HR does police. People can be very slaphappy with recruitment and people issues because they think 'this is not what I'm here to do'...so we [HR] make sure we hold the line on how people are treated in the business.'

In this 'policing' role, HR specialists were responsible for generating policies that would ensure compliance to anti-discrimination legislation and the enforcement of these policies (Liff 1999). These policies emphasised procedural fairness by emphasising neutral treatment and selecting people on the basis of their merits. Complying with such policies meant that staff appeared to be 'neutral' in employment decisions. Demonstrating neutrality in formal written policies provided a document trail that could be used to defend the organisation if it were subjected to a claim of unfair discrimination. For example, in relation to the selection of individuals with disabilities one of the UK high street recruitment manuals stated that:

'Managers need to ensure that every employee or applicant for a job is treated fairly and consistently in other words, the same. The fact that someone has a hearing impairment or is partially sighted...is irrelevant to your selection and promotion methods.' 
Indeed, because official policies equated workplace fairness with treating people the same, 'in practice' respondents perceived differential treatment as wrong, as implied in the following comment taken from a UK store manager.

'We don't treat anybody differently, certainly in this store and in other stores I've worked in. We treat everybody exactly the same.'

However describing their real life experiences of fairness in the workplace contrasted with how many interviewees responded to the fictitious HR scenarios. Commenting on the HR scenarios, interviewees perceived treating people differently according to their individual needs as being more 'fair' than treating everyone the same in the employment relationship.

Avoiding claims of unfair discrimination was especially important for the US and UK high street SBUs. The size of these organisations, their prominent store locations and for the UK high street SBU in particular, the lengthy presence (over 200 years) it had had in British retailing meant that both businesses were well-known amongst the general public. The visible nature of these retailers would therefore mean that involvement in a tribunal would undoubtedly attract negative publicity that could ultimately have a damaging impact upon the reputation of the SBUs. A US HR specialist's comments highlighted the importance of demonstrating procedural fairness in interviews:

'We had a situation where a manager asked an applicant 'Are you married?' When I heard about it I said 'We did what?' The manager can't do that because 
that's so illegal. We could go to court, we could lose and we would have to pay out lots of money.'

Given the size and structure of the US and UK high street SBUs, treating people the same also ensured that the employment relationship was manageable. As the following comment taken from an interviewee in the UK high street SBU highlights, recognising the different employment needs of a large number of staff does not always lead to business benefits as the managing diversity literature suggests. This US respondent was remarking on the problems associated with recognising differences in HR policies:

'If there are 20,000 or so [employees] in an organisation, each employee might want something different out of the company. It would be a nightmare to organise wouldn't it?

In contrast, the online $\mathrm{SBU}$, because of its size and structure, was able to recognise employee differences in policies more so than the US and UK high street SBUs. The number of staff employed at the online SBU had rapidly risen from 10 to 110 in 5 years. This SBU did not have records relating to the diversity profile of the workforce but based on observations by the researcher, staff had visible diversity in terms of age, race, gender and disability. Because of this rapid growth, job roles frequently changed and responsibilities were less rigid and distinct than in the US and UK high street SBUs. All staff were located in one UK premises. This combined with the fact that the numbers employed were relatively small and most staff knew one another meant that the SBU had a flat, loose organisational structure and little bureaucracy. This 
lack of bureaucracy can also be attributed to the nature of e-commerce more generally. Before 2001 the online SBU had operated autonomously and shared similarities with other 'dot com' companies in that activities concentrated on increasing cash flow in the short term and improving share prices (Vlamis and Smith 2001). Formal policies were therefore only introduced as necessary, usually as a consequence of employing more staff as indicated by the following comments taken from a customer service manager:

'Online is slowly changing and evolving. I think because we've started to realise that we're dealing with a large amount of staff now, you need to have procedures in place... but when I compare us to my wife's job at the university where procedures are laid out as soon as you get there, I think 'God, I love this company because it's such a relaxed atmosphere.'

In 2001 the online SBU had gradually begun to be formally integrated into the rest of the retailing group and as a consequence the HR specialist began to engage in administrative duties such as developing a staff handbook. Nevertheless, the SBU still had independence and flexibility in many of its day-to-day staffing activities. For example, one line manager described how the online SBU was able to meet the individual requirements of one employee.

'Somebody came to see me for a review. I offered her a pay rise, she said 'Can I negotiate with you? I would like to work fewer hours for the same money rather than have a pay rise'. She said that because she needs the time to do her 
college course. So we thought about it and it's probably not standard practice but because she's committed to the job we decided that we could meet her request.'

Rather than conform to formalised policies that stated how staff should be treated as managers in the UK high street and US SBUs did, managers in the online SBU were more comfortable with exercising judgement and entering into 'ad hoc' employment arrangements. This increased the scope for differential treatment. The working environment of the online SBU also meant that the outcomes of such decisions were less visible and, arguably, less likely to be questioned as a result, as indicated by the following comments from a senior manager:

'We probably go out of our way here to make employees' lives easier...you'd probably be horrified at some of the things we do and I'm not sure we'd get a favourable response from anyone at the Group. But it's within our discretion I think.'

\section{Discussion and Conclusion}

There is no doubt that, in theory, diversity management, particularly in relation to recognising people at an individual level is appealing (Gordon et al. 1991). Indeed remarks made in response to the scenarios in this study suggest that people, in theory, perceive treating people according to their individual needs as more just than ignoring the diversity of customers and employees in their activities. The attraction of differential treatment is also apparent in the increasing number of retailers incorporating diversity statements in their company literature. B\&Q in their social responsibility booklet, for instance, have highlighted the business case for valuing different inputs from employees - a key principle underpinning the managing 
diversity approach. They state that 'our people are the tools of our trade and we know how important it is to value their individual contributions...our market share keeps growing because we get better at meeting their many different needs'(B\&Q 2003). Similarly Asda (2004), nominated in the top ten UK companies to work for by the Sunday Times newspaper for three successive years, has adopted a diversity strategy based on 'opportunities for all'. So for example, in support of cultural tolerance the company operates a policy of Religious Festival Leave which allows colleagues to take leave to attend any religious festival.

Yet as this study has shown, diversifying products and services to meet different customer needs and adopting a flexible employment relationship that recognises the varying requirements of staff does not necessarily secure business advantages, as many diversity management advocates naively claim. The reality is that the business case for managing diversity is more convincing for retailers whose organisational context lends itself to differential treatment. The argument that the business case for managing diversity and more generally the implementation of the approach is dependent upon a number of elements shares similarities with those arguments put forward by Dickens (1994). Dickens (1994, p. 5) was considering elements in relation to equality more generally, but her comments are nevertheless relevant to the argument put forward here. She proposes that the business case arguments are contingent and 'receptiveness to them... is likely to be uneven...'. Indeed as this study has indicated, organisations may find reflecting different customer requirements in their products and services more appropriate than accommodating different employee needs or vice versa, depending on the environment they operate in. 
The findings of this study indicate that recognising employee and customer differences in retailing activities is not as straightforward as the diversity management literature suggests. This is particularly apparent in the way in which people's responses to the scenarios contrasted with their experiences of diversity management in practice. When commenting on actual experiences, the interviewees provided much more complex and often different interpretations to those they had given in relation to similar issues in the scenarios. The extent to which the retailing SBUs in this research could implement policies of differential treatment was affected by the context in which they operated. For the UK high street and US SBUs this led, on the whole, to a defensive approach to diversity management. The size, structure and method of selling in these more traditional 'bricks and mortar' retailing SBUs limited the degree to which they were able to recognise individual differences. Both these SBUs employed large numbers of staff, had a bureaucratic structure and a formalised approach to the employment relationship. Consequently there was emphasis on treating staff the same in order to demonstrate compliance to antidiscrimination legislation and to keep the employment relationship manageable, thus restricting their ability to recognise individual staff differences. The absence of guidelines in the diversity literature on how to manage staff differences in geographically dispersed workforces may well be because the reality is that, as this research suggests, it is too problematic to do so. Compared to the online selling environment, selling through stores also limited the extent to which these SBUs were able to reflect different customer needs in their products and services. Furthermore, it would appear that management at the UK high street operations appeared to favour defending their 'mainstream' corporate image. According to respondents, diversifying 
their offerings to reflect the nature of the local market would have proved to be too challenging and risky.

In contrast, because the online SBU's selling environment relied on less traditional electronic means and their selling space was relatively unrestricted, their product range represented a wide range of customer interests. Employing in one premises far fewer people than the US and UK high street SBUs and having a less rigid structure also meant that a flexible employment relationship which took into account the different needs of employees existed.

Contrary to what might have been expected, this research suggests that the legal, cultural and historical differences between the UK and US have not led to the US managers dealing with diversity issues in a radically different way from their UK counterparts. Although the US SBU had more ethnic diversity than the UK high street operations, staff at both the UK high street SBU and the US SBU regarded too much recognition of differences as risky and difficult to manage. On a day-to-day basis managers in both these retailers preferred a 'no difference' approach to the employment relationship and offering more or less the same products and services to customers. This similar approach to the employment relationship can perhaps be partly explained by the UK's legislative approach to equality being initially informed by US law, particularly the Civil Rights Act of 1964 (Bowers 1990). Instead, the most significant differences appear to relate to organisational size/structure and the selling environment. In essence, an entrepreneurial, loosely structured, flexible organisation, in this study typified by the online SBU, was able to treat customers and employees differently, more so than the 'traditional' retailing SBUs whose reliance on 'bricks 
and mortar' stores and clearly structured and bureaucratic organisational context constrained their ability to manage diversity.

It is acknowledged that it is difficult to make generalisations from work that draws upon research in one retailing group, albeit 3 different SBUs within that group. However this study has provided insights that would be useful for other retailers, especially those with multiple outlets and different SBUs, intending to adopt a diversity management approach. Recognising how their organisational context will impede or promote adoption of an approach that acknowledges customer and employee differences is fundamental. In other words a 'home-grown' approach to managing diversity rather than a 'one size fits all' approach which takes proper account of internal and external factors is favoured (Boxall and Purcell 2002). This will create a much more realistic perception of diversity management implementation that, at present, the literature lacks.

Diversity management is increasingly featuring on retailers' strategic agendas yet is in an issue that is given only limited consideration in the retailing literature. Further research would therefore be welcomed in this area. Specifically since this paper advocates a 'home-grown' solution to diversity management it would be of interest to understand how other retailers implement diversity management. Conducting research in different retailers that might vary according to their selling environment or their size and structure may ultimately help to establish 'good-practice' rather than 'best-practice' guidelines for retailers wishing to implement a managing diversity approach. 


\section{References}

Agocs, C. and Burr, C. (1996) 'Employment equity, affirmative action and managing diversity: assessing the differences', International Journal of Manpower, 17(45): 3045.

Asda (2002) 'Eyes down, Asda's looking for a full house: Asda's recruitment team head for bingo halls in its search for older workers' www.asda.co.uk (accessed 22/06/04).

ASDA (online) (cited $17^{\text {th }} \quad$ April 2004). Available from <URL:http://www.asda.co.uk>.

B\&Q (2003) B\&Q Social Responsibility: climbing the ladders, Eastleigh: B\&Q.

Barmes, L. and Ashtiany, S. (2003) 'The diversity approach to achieving equality: potential and pitfalls', Industrial Law Journal, 32(4): 274-296.

Bond, M. and Pyle, J. (1998) 'Diversity dilemmas at work', Journal of Management Inquiry, 7(3): 252-269.

Bowers, J. (1990). Bowers on Employment Law, $4^{\text {th }}$ ed. London: Blackstone Press Limited.

Boxall, P. and Purcell, J. (2002) Strategies in Human Resource Management, Basingstoke: Macmillan.

Broadbridge, A. (2000) 'Stress and the female retail manager', Women in Management Review, 15(3): 145-156.

Bryman, A. (1989) Research Methods and Organization Studies, London: Routledge. Cartwright, S. and Cooper, C. (2000) HR Know-How in Mergers and Acquisitions, London: IPD. 
Cassell, C. (2001) 'Managing Diversity', in Redman, T. and Wilkinson, A. (ed.) Contemporary Human Resource Management: text and cases, Harlow: Pearson Education Limited.

Caudron, S. (1994) 'Diversity ignites effective work teams', Personnel Journal, 73(9): 54-63.

Copeland, L. (1988) 'Valuing diversity, part 1: making the most of cultural differences at the workplace', Personnel, 65(6): 52-60.

Cox, T. (1993) Cultural Diversity in Organizations: theory, research and practice, San Francisco: Berrett-Koehler Publishers.

Dickens, L. (1994) 'The business case for women's equality: is the carrot better than the stick?', Employee Relations, 16(8): 5-18.

Dreze, X., Hoch, S. and Purk, M. (1994) 'Shelf management and space elasticity', Journal of Retailing, 70(4): 301-326.

Engel, J., Blackwell, R. and Miniard, P. (1995) Consumer Behaviour, $8^{\text {th }}$ ed., Forth Worth: The Dryden Press.

Frankwick, G., Ward, J., Hutt, M. and Reingen, P. (1994) 'Evolving patterns of organizational beliefs in the formation of strategy', Journal of Marketing, 58(April): 96-110.

Fredman, S. (2001) 'Equality: a new generation?' Industrial Law Journal, 30(2): 145168.

Gill, P. (1996) 'Managing workforce diversity - a response to skills shortages?', Health Manpower Management, 22(6): 34-37.

Gordon, G., DiTomaso, N. and Farris, G. (1991) 'Managing diversity in R\&D groups', Research Technology Management, 34(Jan/Feb):18-23. 
The Grocer (1998) 'Deli first claimed by JS', The Grocer, Crawley, 31 ${ }^{\text {st }}$ October, p.14.

Harris, L. (1999) 'Employment law and human resourcing: challenges and constraints', in Leopold, J., Harris, L., and Watson, T. (ed.) Strategic Human Resourcing: principles, perspectives and practices, London: Financial Times Pitman Publishing.

Harris, L. (2000) 'Procedural justice and perceptions of fairness in selection practice', International Journal of Selection and Assessment, 8(3): 148-157.

Hebburn, S. (2003) HSBC offers Islamic financial products, Race for Opportunity Update, Winter: 3 .

Hepple, B. (2001) 'Equality and empowerment for decent work', International Labor Review, 140(1): 5-18.

Herriott, R. and Firestone, W. (1983) 'Multisite Qualitative Policy Research: optimizing description and generalizability', Educational Researcher, 12: 14-19.

Hogarth, T. and Barth, M. (1991) 'Costs and benefits of hiring older workers: a case study of B\&Q', International Journal of Manpower, 12(8): 5-17.

Initiative for a Competitive Inner City (1998) \$ $\$ 85$ billion retail opportunity in America's inner cities: first definitive study on American inner-city retailing', www.icic.org (accessed 22/06/04).

John Lewis Partnership (online) (cited $4^{\text {th }}$ August 2004). Available from <URL:http://www.johnlewispartnership.co.uk>

Johnson-Hillery, J., Kang, J. and Tuan, W. (1997) 'The difference between elderly consumers' satisfaction levels and retail sales personnel's perceptions', International Journal of Retail \& Distribution Management, 25(4): 126-137. 
Kandola, R. and Fullerton, J. (1994) 'Diversity: more than just an empty slogan', Personnel Management, 26(11): 46-50.

Kandola, R. and Fullerton, J. (1998) Diversity in Action: managing the mosaic, $2^{\text {nd }}$ ed., London: CIPD.

Kirton, G. and Greene, A. (2000) The Dynamics of Managing Diversity: a critical approach, Oxford: Elsevier Butterworth-Heinemann.

Lewis, S., Kagan, C. and Heaton, P. (2000) 'Managing work-family diversity for parents of disabled children: beyond policy to practice and partnership', Personnel Review, 29(3): 417-430.

Liff, S. (1999) 'Diversity and equal opportunities: room for a constructive compromise?', Human Resource Management Journal, 9(1): 65-75.

Marshall, C. and Rossman, G. (1995) Designing Qualitative Research, Thousand Oaks: Sage Publications Inc.

Mavin, S. and Girling, G. (2000) 'What is managing diversity and why does it matter?', Human Resource Development International, 3(4): 419-433.

McEnrue, M. (1993) 'Managing diversity: Los Angeles before and after the riots', Organizational Dynamics, 21(3): 18-29.

McGoldrick, P. (2000) Retail Marketing, $2^{\text {nd }}$ ed., London: McGraw-Hill.

National Statistics (2002), www.statistics.gov.uk (accessed 20/11/02).

Newsweek (2000) 'America 2000: a map of the mix', Newsweek, New York, September $18^{\text {th }}$, p.74.

Pickard, J. (1999) 'Equality counts', People Management, 5(22): 38-42.

Prahalad, C. (2004) The Fortune at the Bottom of the Pyramid: eradicating poverty through profits, London: Financial Times Prentice Hall. 
Retail Week (2001) 'Recruitment crisis -ooh, recruits you, sir!', Retail Week, London, $20^{\text {th }}$ April, p14.

Schneider, R. (2001) 'Variety performance', People Management, 7(9): 26-31.

Shanmuganthan, P., Dhaliwal, S., Stone, M. and Foss, B. (2003) 'Does ethnic focus change how banks should implement customer relationship management', Journal of Financial Services Marketing, 8(1): 49-62.

Sheffield, J., Hussain, A. and Coleshill, P. (1999) 'Organisational barriers and ethnicity in the Scottish NHS', Journal of Management in Medicine, 13(4): 263-284. Tesco (online) (cited $4^{\text {th }}$ August 2004). Available from <URL:http://www.tesco.com>. Thomas, D. and Ely, R. (1996) 'Making differences matter: a new paradigm for managing diversity', Harvard Business Review, 74(5): 79-90.

Thomas, R. (1990) 'From affirmative action to affirming diversity', Harvard Business Review, March-April: 107-117.

Uncles, M. (1995) 'Viewpoint: securing competitive advantage through progressive staffing policies', International Journal of Retail \& Distribution Management, 23(7): 4-6.

Vlamis, A. and Smith, B. (2001) Business the Yahoo! Way, Milford: Capstone Publishing Inc.

Whitehead, M. (1999) 'A time for buy-in', People Management, 2(11): 54-56.

Wilson, E. and Iles, P. (1999) 'Managing diversity - an employment and service delivery challenge', The International Journal of Public Sector Management, 12(1): $27-48$.

Wright, M. and Storey, J. (1997) 'Recruitment and selection' in Beardwell, I. and Holden, L. (ed.) Human Resource Management: a contemporary perspective, $2^{\text {nd }}$ ed., London: Pitman Publishing. 
Yin, R. (1994) Case Study Research: design and methods, $2^{\text {nd }}$ ed., Thousand Oaks: Sage Publications. 


\begin{tabular}{|c|c|c|c|c|}
\hline SBU & Size & Structure & $\begin{array}{l}\text { Annual sales at } \\
\text { the time of the } \\
\text { study }\end{array}$ & Established \\
\hline $\begin{array}{l}\text { UK high } \\
\text { street }\end{array}$ & $\begin{array}{l}550 \text { high street/out-of- } \\
\text { town stores throughout } \\
\text { the UK, } 17,000 \text { staff, } \\
\text { approximately } 500 \\
\text { employees in head } \\
\text { office. }\end{array}$ & $\begin{array}{l}\text { Head office } \\
\text { level, } 6 \\
\text { regional } \\
\text { levels and } \\
\text { store level }\end{array}$ & $£ 1120 \mathrm{~m}$ & 1792 \\
\hline US & $\begin{array}{l}570 \text { airport and hotel } \\
\text { stores throughout } \\
\text { Canada, South and North } \\
\text { America, } 3,600 \text { staff, } \\
\text { approximately } 200 \text { staff } \\
\text { in head office }\end{array}$ & $\begin{array}{l}\text { Head office } \\
\text { level, } 5 \\
\text { regional } \\
\text { levels and } \\
\text { store level }\end{array}$ & $£ 245 \mathrm{~m}$ & 1985 \\
\hline Online & $\begin{array}{l}\text { Website/interactive } \\
\text { channels, } 110 \text { staff }\end{array}$ & $\begin{array}{c}\text { Centrally } \\
\text { located in one } \\
\text { UK premises }\end{array}$ & $£ 8 \mathrm{~m}$ & 1999 \\
\hline
\end{tabular}

$\underline{\text { Table 1: Key structural differences of the case retailers }}$ 